\title{
Crisis, (re-)informalisation processes and protest: The case of Barcelona
}

Marc Pradel-Miquel

Departament de Teoria Sociològica, Filosofia del dret i Metodologia de les Ciències Socials

Universitat de Barcelona

marcpradel@ub.edu

\begin{abstract}
:
Analyses of responses to the crisis in Southern European cities have underlined political unrest and social mobilization as the result of growing inequality and the imposition of cuts. This article analyses these responses in terms of the return of reciprocity practices in a context of weakening citizenship rights. From this point of view, these responses can be understood as forms of informality as is analysed in cities of the global south. Citizens' self-organisation to cover basic needs can be read as strategies of resistance such as quiet encroachment. Some of these strategies are politicized, becoming part of the political struggle for rights. Through the case of Barcelona, this article analyses how different groups are politicizing these practices and by focusing on the case of subSaharan migrants living in abandoned factories in the city in particular. The analysis shows how in the context of weakening or the absence of citizenship rights, there is a growth of informal practices that can be unevenly politicized by different groups.
\end{abstract}

Keywords: informality, citizenship rights, social mobilization, southern European cities, Barcelona

\section{Introduction}

Since its first use in the seventies (Hart, 1973), the concept of 'informality' has been used to analyze how the social practices of the urban poor have contributed to shaping cities in the global south. These practices, subject to exploitation and social inequality, can be considered an adaptation process of the poor to the changing pressures of capitalism in an urban context. In this regard, 'urban informality' refers to a set of nonregulated social practices that allow marginalized groups to create mechanisms to cover their material and immaterial needs. Understood in this sense, 'urban 
informality' affects the physical structure of cities, the set of social relations that happen in them as well as forms of collective behavior and social control. The analysis of these practices has focused on economic implications and on their political dimensions, including the political groundings of the causes that lead to marginality and informality, the relation of informality with community empowerment (McFarlane and Rutherford, 2008; Roy, 2005) and the role played by informality in economic growth (McFarlane, 2012b; Soto, 1995).

This article analyses the re-emergence of informal practices in the city of Barcelona in the context of the financial crisis and the imposition of austerity policies. It proposes drawing attention to these practices to better understand the social movements against cuts and austerity in the city. The starting hypothesis is that the weakening of social rights brought about by the cuts has meant the use of informal practices as a means of survival and, in some cases, its politicization in terms of demands for rights. The article focuses on this uneven politicization, analyzing different sets of practices and paying special attention to the practices of informality developed by migrants in Poblenou, a neighborhood that has seen the re-emergence of informal settlements. There, the urban poor have been squatting in old factories and empty lots, rehabilitating them as spaces for housing and work and specializing in the collection of garbage. The article analyses the attempts of a group of migrants to continue with their settlement trying to negotiate and to formalize their situation. The analysis is based on the collection of secondary data of the different sets of practices, including official reports, documents developed by neighborhood associations and social movements and media coverage of the emergence of informal practices. The article is 
also based on participant observation of an informal settlement of migrants in the Poblenou neighborhood, based on three visits to the settlement and participation in the migrant protests and demonstrations of June and July, 2013.

The article is structured as follows: Firstly I present a theoretical reflection on the role of informality in cities during the current crisis. I then analyze the case of Barcelona, including an analysis of its historical trajectory, the rise of social inequalities with the economic crisis and the role that informality has been playing as a form of survival and protest for different groups. The article then draws conclusions on the case and establishes possible lines for further research.

\section{Informality as a source of social response to the crisis}

The changing role of welfare states has brought increased attention to selforganization and citizen-based organization. Crisis and austerity have meant a rise in unemployment and inequality, as well as consequences for the provision of housing, the downgrading of public services on the local level and constraints to public spending. This is especially true in southern European cities where social inequality has risen due to the perverse effects of long-term unemployment and the withdrawal of social policies. This situation has led to the emergence of individual and community initiatives based on self-organization and co-production of policies and services not being covered by public administration or the private market. These initiatives, being depicted as socially innovative strategies or as low-budget initiatives (Hilbrandt and Richter, 2015) refer to new forms to cope with the constraints in everyday life.

These practices are can be understood as tools for the implementation of neoliberal urbanism and the transfer of responsibility in the provision of welfare from state to 
society (Rosol, 2012). Different governments and supranational institutions propose social imagination to develop new forms of collective organization (Murray et al., 2010) as possible solutions to new challenges created by the expansion of markets and the withdrawal of the state. In front of these proposals a group of scholars has linked these practices to social justice, emphasizing that social innovation entails fighting uneven power relations (Moulaert et al., 2013; Swyngedouw et al., 2005). From the point of view of policy proposals, many of these approaches propose solutions based on the co-participation of citizens in the design and delivery of policies, especially at the local level.

Nevertheless, this research only partially covers the emergence of non-state and nonmarket forms or organization in the context of cuts and crisis. From a regulatory perspective on governance (Le Galès, 2002, 2011), reciprocity mechanisms grow ahead of redistributive mechanisms. Regulation based on reciprocity takes multiple forms including family solidarity, the neighborhood organization of services and the creation of solidarity networks. However, it also means patronage and corruption and the growth of illegal activities (Le Galès, 2011; Mingione, 1994). To understand local forms of regulation, we must draw our attention also to the invisible activities, including the illegal ones, which are an integral part of the city itself (Le Galès, 2011). As we will see through the case of Barcelona, part of the practices based on self-organization to face the effects of the crisis and the cuts have become politicized and reframed in terms of rights. To understand these practices, I suggest enriching the analysis by focusing on the connection between informal practices and the governance of the city. 
Researchers on informality have focused on the role of the 'ordinary people' (Bayat, $1997,2013)$ in developing practices beyond the state, including the development of entire neighborhoods, the informal occupation of the public space, forms of economic development and other practices largely based on reciprocity and self-organization. Debates on the role of these initiatives in the city and its management are similar to those emerging from a more recent analysis of European cities. Schematically, informality has been depicted as: a) a useful tool for providing economic growth and prosperity in the context of capitalism, b) a tool used by states to reinforce neoliberal urbanism and c) as a form of resistance and a source and a possible basis to develop of political mobilization (Varley, 2013).

This article fits in this third line of research, which has focused on the organization of informal practices and its possibilities in becoming or influencing political and social movements (Bayat, 1997; McFarlane, 2012a, 2012b; Scott, 1989). Scott (1989) analyzed informal practices by peasants as forms of political resistance against the state and its modernization, stressing that lower classes without rights develop 'hidden' forms of political mobilization consisting of 'everyday forms of resistance'. More recently, Bayat $(1997,2013)$ analyzed the development of informal ordinary practices in the Middle East and Latin America as a form of struggle, even though they differ from ordinary social movements (Bayat, 1997: 57). This struggle is based to a great extent on strategies for quiet encroachment, that is, 'quiet and atomized actions by the poor with episodic collective action to modify the pre-existing composition of forces' (Bayat, 2013: 46). MacFarlane, when analyzing Mumbai slums (McFarlane, 2012a, 2012b) stresses the process of politicization of informal organization and its 
negotiation capacity (or not) with authorities, stressing the relation between formal and informal over time and how the politics of formalization are being developed.

These approaches can be useful to understand the emergence of bottom-up practices and their role in the forms of local regulation in European cities, as they allow to understand the role of government and other governance actors in formalization and informalization (as other authors have done, see for instance Fairbanks, 2011; MacLeod \& Jones, 2011; Simone, 2004). In European cities, lower classes are embedded in a governance system that formally recognizes civil, political and social rights, and that has generated mechanisms and institutions to grant these rights such as local welfare policies, local ombudspersons and participation mechanisms in city decision-making. Despite the fact that only citizens have full recognition of rights, cities have tended to develop policies to ensure the social citizenship of foreigners, fostering forms of urban citizenship (Isin and Turner, 2007). This means, in terms of governance, that migrants and foreigners have been governed through different mechanisms based on inclusion and integration policies and community-based approaches rather than formally participating in policy-making.

These models have been developed later and in a more fragile way in Southern European cities as to a large extent, citizenship rights were established quite recently in these countries ${ }^{1}$. Furthermore, austerity measures have meant a weakening of this model. Healthcare, housing, education and social integration policies have suffered severe cuts, which hamper the effective fulfilment of formal rights. Debilitating

1 Portugal, Spain and Greece were developed in a framework of dictatorships and citizenship rights were not fulfilled until the seventies and were then consolidated during the eighties. 
mechanisms for urban citizenship and growing unemployment have brought noncitizens to increasing vulnerability, but also has weakened the possibility for citizens with recognized rights. Groups of citizens and non-citizens are forming the new urban poor (Kaika, 2012) which relies on informality as a strategy for survival and as a form of protest. This group is key to understand protest and mobilization in southern European cities, and we cannot neglect the role that informality is playing in these actions.

The connection between informality and mobilization should be analyzes instead, paying closer attention to the politicization processes and the relationships of these groups with local government. We need to analyze also the role and attitude of different levels of government towards self-organization at the margins of the state: what kind of practices are they willing to formalize and what other practices remain illegal and marginal and why does this happen? Finally, the role of the constellation of actors regarding such practices must also be analyzed. To test this approach, the next section presents the case of Barcelona, a city strongly affected by the crisis where informal practices have emerged and been enmeshed, giving place to new political demands. To analyze these aspects and their relation in terms of governance, we will focus on informal practices from cities and a specific informal initiative taken by a large group of sub-Saharan migrants.

\section{An informality-based reading of bottom-up initiatives in Barcelona}

Since its industrialization and expansion, informal practices have been a relevant part of the local regulation of Barcelona, it has even influenced the city's physical development. The weak modernization of Spain brought a lack of consolidation of 
citizenship rights. Following Marshall's approaches (1950), as civic and political rights were weak, there was no room for the consolidation of social rights. This resulted in working class movements for the modernization of the state, but also movements based on a lack of trust and self-organization, which felt attracted to anarchist views.

The rapid growth of Barcelona during the nineteenth century meant new working class neighborhoods in which self-organization was the main mechanism regulating social life and weak intervention of the state. By the beginning of the twentieth century migration flows continued to arrive to Barcelona and the built city was filled, giving place to the first slums on its outskirts. Another wave of migration came to the city during the Francoist dictatorship (1939-1977), especially after the economic recovery taking place since the 1950 s when there was a certain liberalization of the economy. This migration relied on informal practices as a way for survival but also as a form of resistance in the absence of political and civil rights.

The process of urban growth taking place during the dictatorship was based to a great extent on a weak or noncompliant state regulations and thus on a strong role of informal practices of two kinds: practices developed by the urban poor (informal housing and urbanization, informal economy and the creation of slums) and practices developed by private companies, which developed housing states without urbanizing the area and without creating facilities). Neighborhood associations won a relevant role in the organization of informal practices during the seventies and their transformation into political demands. In fact, neighborhood associations were pushing for the recognition of rights and the formal intervention of the state in the 
resolution of problems and creation of infrastructures ${ }^{2}$, pressing for the formalization of informal housing, the relocation of slum dwellers in social housing and the creation of public facilities for disenfranchised neighborhoods. With the return of local democracy since 1979, the city councils of the Barcelona metropolitan Area, mainly led by leftist parties, deployed this political agenda in close connection to neighborhood associations.

The city council developed a local welfare system based on collaboration and consensus between civil society actors including NGOs, neighborhood associations, and other groups and the city council. During the eighties social policies and urban infrastructures were developed, especially in the disadvantaged neighborhoods. The proclamation of the city as the host of the Olympic games of 1992 consolidated the physical transformation of the city and allowed for the eviction of the last slums and the relocation of its population. These policies brought also an improvement of quality of life through the improvement of public space (Degen and García, 2012; Degen, 2008) and a reduction of the gap between rich and poor neighborhoods

These policies reinforced the consolidation of a middle class in the city, with informal practices being relegated to migrants and extremely poor people. With the increase of international migration flows to Barcelona since 1998, informality has been increasingly linked with migrants, especially the emergence of informal activities linked to the services economy. Since then, new activities such as street vending, offering

\footnotetext{
${ }^{2}$ At that time, several leaders of working class movement were exiled in Europe and they brought ideas such as Lefevbre's 'Right to the city'into the political agenda of urban social movements (Andreu, 2015: 24-25).
} 
services and products on the beach and domestic services grew in parallel to a context of national economic growth.

Despite migrants suffering a lack of citizenship rights, the city government promoted, in collaboration civil society actors, a network to offer possibilities of integration and representation in the city for migrants (Godàs and Gomà, 2008). Migrants' associations were integrated into the governance model of the city, and informal activities were fought through a combination of repression and negotiation. Nevertheless, the impact of these model was uneven amongst different migrants' groups and activities. For instance, street vending of copyrighted material, mainly developed by sub-Saharan migrants, suffered a severe repressive policy following pressures from above.

This local welfare system was weakened with the arrival of the crisis. Like all of Spain, poverty and social inequality in Barcelona has grown steadily since the beginning of the economic crisis in 2008. The burst of the speculative bubble and the rise in unemployment brought a social housing emergency, as many owners could not pay their mortgages and were evicted (De Weerdt and Garcia, 2015). Between 2008 and 2010 there were 12, 657 evictions in the Barcelona province, which means 15.6 evictions per day (Colau, 2011). Evictions and unemployment are concentrated in certain parts of the city, giving rise to a pattern of spatial polarization following the spatial distribution that shaped in the nineteenth century.

These trends have been reinforced by cuts in the welfare system. Between 2010 and 2015, public spending in Catalonia ${ }^{3}$ suffered significant cuts in education (17\%) health

3 In Spain responsibilities on welfare fall to a large extent under the regional level. 
(14.5\%), housing (60\%), and active employment policies (25\%) 4 . Moreover, between 2011 and 2015 a conservative liberal coalition governed the city for the first time since the return of democracy reinforcing a neoliberal approach on urban development.

All this has challenged the local welfare model and weakened social rights in the city. In first place, policies and organizations developed to fight poverty and social exclusion have seen a huge increase of users. For instance, the Catalonia food bank provided food to 57,381 people in Barcelona in 2008, five years later, it covered four times more people, reaching 146,286 users (Pomar and Tendero, 2015: 34). During this period, local social emergency budgets were increased whereas other policies to fight social exclusion were limited to avoid a growing number of beneficiaries.

This context of crisis and strong deprivation fostered the emergence of informal practices from the new urban poor, practices that sometimes complement the social benefits and programs existing in the city. In the period 2008-2015 we saw an uneven politicization of these practices and the creation of new mobilizations in terms of rights. In the following sections we will analyze these trends.

\section{Informal practices and mobilization against the weakening of citizenship rights}

In Spain the crisis has brought a new cycle of mobilizations that starts with the $15 \mathrm{M}$ movement in May $2011^{5}$ and includes a wide range of mobilizations in different fields such as housing, energy supply, health, or education, amongst others. The success of

4 Source: http://www.elcritic.cat/blogs/sentitcritic/2015/09/04/lestat-de-la-catalunyasocial-davant-les-eleccions-del-27-s/ seen on 15 October 2015.

5 The 15M movement started as a massive demonstration protest in main cities of Spain claiming for better democracy and against political corruption before the municipal elections in May 2011. Copying strategies from the Arab Spring, the demonstration led to camps in the main squares of Spanish cities demanding for political reform. 
these protests can be understood looking at the role of daily practices for survival and its progressive legitimation in reaction to the inaction of the state in the provision of rights, the imposition of austerity policies to rescue the banking system and the generalization of corruption in the political class. The emerging forms of protest and social action can be read as a combination of social movements that existed before the crisis with forms of quiet encroachment ensuring the provision of minimal living standards (Bayat, 1997).

Through the crisis, the informal provision of food, water, energy and housing has been increasingly seen as legitimate practices for three reasons. The persistence of the crisis and unemployment has brought citizens to look for mechanisms of subsistence apart from the labor market mechanisms. This meant the growth of informal work but also the growth of practices of self-provision for resources including energy, water and living space. The imposition of cuts and neoliberal agendas on local, regional and national levels has also encouraged the perception that these informal practices are legitimate forms of resistance in reaction to the cuts and the political situation. This connects directly to the third element, the perception of the growing inequality and the existence of an economic and political elite that is benefitting from the crisis. The perception of corruption amongst the political class, the role of the banking system in the crisis and the increasing role of private actors in the management of basic sectors such as water and energy has legitimated the practices as everyday forms of resistance put in motion by the poor against the established powers (Scott, 1989).

This legitimation differs from one practice to the other. The acquisition of piped water, electricity and gas has been based to a large extent on individual (household) direct 
action based on being unnoticed and informal transmission of knowledge between neighbors. However, media attention of impoverished neighborhoods and increased control by energy companies over these areas imposing fines and cutting services ${ }^{6}$ has limited the possibility for these kinds of solutions. In parallel, neighborhood associations and other social movements fighting for the right to these services have created the Alliance against Energy Poverty, a group claiming the recognition of these services as rights and their coverage by companies. They demand also for public action against the rise of prices in electricity and water ${ }^{7}$. These pressures have brought the city council to approve a fund to cover the cost of the services for those who cannot afford to pay. Nevertheless, the movement has gone a step further in its demands, claiming for remunicipalization of these companies and the decommodification of water, electricity and gas.

The legitimation of informal practices and their use as a tool for political demands is stronger in the case of housing. As in other southern European countries, in Spain, ownership is an extended practice that nurtured the speculative bubble of construction since 1998. During the economic growth period, squatting was strongly stigmatized as cheap mortgages allowed for the buying of houses, and the real estate sector pressured for a change to the legal framework to allow rapid evictions for people squatting in a house.

6 In 2012 the water company cut the services to 72,000 households, and 1.4 million families in the whole country suffered an electricity cut. In some cases, even the provision of water in public fountains has been cut (http://pobresaenergetica.es/cronica/20a-cronicafamilies-senceres-amb-menors-les-fosques-sense-aigua-indignant/).

7 Water prices have increased 65 per cent since the start of the crisis in 2008, whereas electricity prices have seen a growth of 83 per cent over the 2013-2015 period http://pobresaenergetica.es/qui-som/ seen on October 17, 2015. 
When the crisis arrived and the number of evictions rose, the first reaction was to use or reoccupy empty buildings for living on the basis of individual responses and being unnoticed when possible ${ }^{8}$. In reaction to the growth of evictions, the government and some media portrayed the victims of evictions as "being guilty of living beyond their means ${ }^{\prime \prime}$. The generalization of resistance against evictions was only possible with the social organization of the affected under the Platform for the Affected by the Mortgage (PAH), which was created in Barcelona (De Weerdt and Garcia, 2015). One of the first and main tasks of the PAH was providing psychological support to victims, showing them that they are not responsible for their situation. This psychological help, together with actions to stop the evictions and political campaigns of PAH to change the law has brought not only a legitimation of squatting but also the use of this practice as a political tool for protest. The fact that dwellings are becoming the property of banks saved with public debt and that these flats remain empty as the banks cannot sell it due to the crisis has helped to legitimate these practices.

Informal practices have therefore gained legitimation as a tool for subsistence and as a form of resistance. In some cases they have brought forms of social organization and politicization around specific projects or political movements, whereas in other cases they have remained in the informal economy sphere without bringing any political movement. In certain neighborhoods of the city, informal practices have become common in daily life and they have been increasingly combined with social protest organized through large social movements. It is important to underline the $15 \mathrm{M}$

8 This was not the only response to the situation. Many evicted started to live with their relatives, mainly parents and grandparents.

9 The expression was coined by the president himself in spring 2012 and was used later to define the growth of private indebtedness of the country as citizens' decision. 
movement in the politicization of these practices and their involvement in wider political protest demanding rights. The link with social movements demanding for rights and these practices that have elements of quiet encroachment are substantial part of the indignados movement.

\section{Informal practices in the absence of formal citizenship rights}

Nevertheless, this politicization of informal practices is uneven. Groups of migrants, especially sub-Saharan migrants, show a weaker ability to articulate demands and their informal activities have been repressed by the city council. Foreigners were the first to lose their jobs, mainly in the construction sector, and were strongly affected by the housing crisis. A significant part of the people who owned a flat and are not able to pay the mortgage are of foreign origin. Furthermore, the poorest sector of foreigners was living in collective flats and were unable to pay the rent. They lost their jobs and their living places, with consequences on their legal status as foreigners.

As a result, many of them have been organizing around informal economic activities and settling in empty lots and abandoned factories in the city, mainly in the former industrial neighborhood of Poblenou. Even though the negibhbourhood was object of large urban renewal plans during the period of the economic boom, lots of old factories remained abandoned as construction activity stopped. These old factories and vacant lots are being used by migrants and the poor in general to create informal housing and new forms of economic activity. Groups of migrants have concentrated in abandoned factories creating new settlements, whereas families and small groups have created informal housing in empty lots. These settlements vary in size from family to large groups of 300 people and some of them are also spaces for economic 
activity. Again, its main strategy has been being unnoticed by authorities and owners and looking for new economic activities.

Most of the dwellers in these factories and empty lots work informally in the recycling sector, collecting scrap, glass, paper and other waste from the whole city. According to data from the city council, in 2013, there were more than 25 squatted factories in which more than 500 immigrants, mainly from sub-Saharan Africa, live and work ${ }^{10}$. In fact, the illegal collection of materials for recycling has been growing in the city. Calculations show that 33 thousand people are employed in scrap collection in Barcelona, with increasing competitiveness as recycling resources are limited. In Catalonia, informal collection covers 22 per cent of the waste recycling and 141 million Euros are spent in buying waste from informal collectors ${ }^{11}$. This activity has meant a threat to formal companies processing metal and other materials for recycling, which pay increasing taxes for their collection work. Despite the fact that the informal collectors could formalize their situation as being self-employed, they preferred to remain informal as they couldn't earn enough money if they had to pay the official taxes. In fact, the collective organization of scrap collection and processing in these old factories has become very professional. One of the larger factories existing (evicted in July 2013) had 300 dwellers and 700 workers worked in the scrap processing, collecting metal pieces, glass, paper, and processing complex elements ${ }^{12}$.

10 Because of the evictions, the number decreased to 20 settlements in 2014, with two major settlements with 300 inhabitants being dismantled in the summer of 2013.

11 All data comes from Recupera $\mathrm{n} .84 \mathrm{http} / / / \mathrm{www}$. gremirecuperacio.org/pdf/revistarecupera/84.pdf (last seen on 20 July 2015)

12 During a two hours fieldwork observation, a team of 10 workers scrapped an abandoned car taking all of its parts. In the factory, all materials were classified and grouped and were sold by weight. 
This concentration of the urban poor started to gain notoriety after a family died in an accident in an empty lot where they had built their informal dwelling in the first months of 2012. One of the main newspapers of the city published articles and reports on the issue ${ }^{13}$, which forced the city council to take measures to avoid the growth of new slums. Additionally, as they were using private spaces, and in most of the cases there was no legal action against it from owners, the city council could not act against these forms of housing. Nevertheless, with the official argument of ensuring health conditions, the city council started a program to avoid the creation of a slum in Poblenou, convincing private owners to expel users of the space, relocating dwellers and giving them support for their integration in the formal labor market. However, the migrants were strongly against this plan for three reasons: in most cases, the migrants couldn't fully participate in the program as they do not have a regular situation after losing their job. Additionally, the relocation plans foresees only a temporary relocation and then they become homeless again. Lastly, and most relevant, these spaces are not only spaces for living but also spaces for developing an economic activity.

Once the strategy of being unnoticed failed, dwellers of the biggest settlements started to organize collective responses to the evictions being planned by the city council. In one of the largest factories, they proposed the creation of scrap collector cooperatives operating with legal status, and negotiating with the owners of the factories $^{14}$, looking for the support of the neighborhood association and the local

13 One of the reports, in video format can be seen at http://www.elperiodico.com/es/videos/barcelona/campamentos-barracas/1336188.shtml (last seen October 17, 2015)

14 The role of experienced leaders such as Ibrahima Seydi, who became the spokesman of the settlement is key to understand the political actions of the dwellers. 
assembly of the indignados movement. In fact, after the deaths in the empty lot, the neighborhood association organized a network supporting the settlements and developed neighborhood initiatives to fight for migrants' rights. These actions were framed as a discourse defending the rights of migrants as neighbors and members of the community. Migrants' strategies have been developing actions to resist with the legal support of these associations and neighbors and trying to formalize their collective economic activity, something that could also solve also their legal status.

Despite demonstrations and having a presence in the media, the large factories were finally evicted and the dwellers were relocated. It is relevant to show how in this case, the city council did not select negotiation or mediation as it did in the case of electricity or water provision for instance, but rather it shifted the question to social policy, providing individual and temporal solutions to dwellers, which solved the problem of negotiating with a collective actor. The solutions were mainly based on providing dwellers of factories with the use of social services facilities for a limited space of time, and giving them advice to regularize their situation. For the factory dwellers, this solution meant weakening the collective organization but losing their source of income in the informal sector. Despite their attempts to bring their informal practices into the legality, even with proposals for formalization of the activity, they were not recognized as a collective actor and there was no negotiation with them, as they lacked citizenship rights.

\section{Conclusion}

Through the case of Barcelona, this article has analyzed how the weakening of citizenship rights after the imposition of austerity policies to southern European 
countries has brought the re-emergence of informal practices as a form of survival for the urban poor, and how these forms of survival can be read as forms of resistance and are unevenly politicized in the demand for rights. In comparison to cities in the 'global south' informal practices can be transformed into political demands for rights and some mechanisms for negotiation and mediation are created. However, those who do not have political rights, such as poor migrants, find this way much more difficult with informality practices and strategies becoming much more similar to those taking place in other cities from the south.

The article has queried the use of literature on informality to understand social movements and protest cuts and austerity in southern Europe. The literature defines informality as a source for politicization and a form of protest that differs from those happening in developed countries. Nevertheless, the concepts and tools developed are useful to understanding current protests in southern European cities not merely because they have faced late processes of modernization being shaped largely through informal practices, but also because these countries are suffering a weakening of social and political rights making it more difficult and ineffective to use the traditional repertoires of social movements.

These parallels call for a more comparative analysis between movements in the global South, such as those linked to the Arab spring, and anti-austerity movements in Southern Europe, analyzing to what extent practices in the latter can be analyzed as varieties of quiet encroachment or the politicization of the informal. The interesting question for analysis is the connection between citizenship rights and the development of informal practices. In the case of Barcelona, the emergence of informal practices 
can be read as the result of a weakening of the coverage of social rights and the feeling

that the state is not providing answers to increasing needs. In this context, informal

practices are combined with, and in some cases are part of, wider mobilizations

demanding change in the political system to ensure full citizenship. In Barcelona, these

mobilizations have fostered the organization of a new political platform reaching the

city council, the Arab Spring however has been less successful in political terms due to

the lack of formal political rights being recognized in many countries (Bayat, 2013).

\section{References}

Andreu M (2015) Barris, veïns i democràcia. Barcelona: L'avenç.

Bayat A (1997) Un-civil society: The politics of the 'informal people'. Third World Quarterly, Routledge 18(1): 53-72.

Bayat A (2013) Life as Politics: How Ordinary People Change the Middle East, Second Edition.

Colau A (2011) Les dades sobre desnonaments a Catalunya i Barcelona. Barcelona.

De Weerdt J and Garcia M (2015) Housing crisis: the Platform of Mortgage Victims

(PAH) movement in Barcelona and innovations in governance. Journal of Housing and the Built Environment, Springer Netherlands.

Degen M (2008) Modelar una 'nueva Barcelona': el diseño de la vida pública. In: Degen M and García (eds), La Metaciudad: Barcelona, transformación de una metrópolis, Barcelona: Anthropos, pp. 83-96.

Degen M and García M (2012) The Transformation of the 'Barcelona Model': An Analysis of Culture, Urban Regeneration and Governance. International Journal of Urban and Regional Research 36(5): 1022-1038.

Delgado M (2007) La ciudad mentirosa: fraude y miseria del 'modelo Barcelona'.

Fairbanks RP (2011) The Politics of Urban Informality in Philadelphia's Recovery House Movement. Urban Studies 48(12): 2555-2570.

García M (2008) Barcelona: ciudadanos y visitantes. In: Degen M and García M (eds), La metaciudad: Barcelona, transformación de una metrópolis, Barcelona: Anthropos, pp. 97-113.

Godàs X and Gomà R (2008) Barcelona: la política de inclusión social en el marco de redes de acción. In: Fleury S, Subirats J, and Blanco I (eds), Respuestas locales a inseguridades globales; innovación y cambios en Brasil y España, Bacelona: Fundació CIDOB, pp. 285-303.

Hart K (1973) Informal Income Opportunities and Urban Employment in Ghana. The Journal of Modern African Studies, Cambridge University Press 11(01): 61-89.

Hilbrandt $\mathrm{H}$ and Richter A (2015) Reassembling austerity research. Ephemera 15(1): 163-180.

Isin EF and Turner BS (2007) Investigating Citizenship: an agenda for citizenship studies. Citizenship Studies 11(1): 5-17. 
Kaika M (2012) The economic crisis seen from the everyday. City 16(4): 422-430.

Le Galès P (2002) European cities, social conflicts and governance. Oxford: Blackwell. Le Galès $P$ (2011) Urban governance in Europe: What is governed ? Array (ed.), The New Blackwell Companion to the City, Wiley-Blackwell: 747-758.

MacLeod G and Jones M (2011) Renewing Urban Politics. Urban Studies 48(12): 24432472.

Marshall TH (1950) Citizenship and social class, and other essays. Cambridge: Cambridge University Press.

McFarlane C (2012a) Rethinking informality: Politics, crisis, and the city. Planning Theory \& Practice.

McFarlane C (2012b) The entrepreneurial slum: Civil society, mobility and the coproduction of urban development. Urban Studies.

McFarlane C and Rutherford J (2008) Political Infrastructures: Governing and Experiencing the Fabric of the City. International Journal of Urban and Regional Research 32(2): 363-374.

Mingione E (1994) Sociedades fragmentadas: sociología de la vida económica más allá del paradigma de mercado. Madrid: Ministerio de Trabajo y Seguridad Social.

Moulaert F, MacCallum D, Medmood A, et al. (2013) The International Handbook on Social Innovation: Collective Action, Social Learning and Transdisciplinary Research. Cheltenham: Edward Elgar

Murray R, Caulier-Grice J and Mulgan G (2010) The Open Book of Social Innovation. Nesta and The young foundation.

Oyón JL (2008) La quiebra de la ciudad popular: espacio urbano, inmigración y anarquismo en la Barcelona de entreguerras. Barcelona: Ediciones del Serbal.

Roca i Albert J (2010) La ciutat informal. In: Tatjer M and Larrea C (eds), Barraques: La barcelona informal del segle XX, Barcelona: Ajuntament de Barcelona, pp. 11-14.

Rosol M (2012) Community Volunteering as Neoliberal Strategy? Green Space Production in Berlin. Antipode 44: 239-257.

Roy A (2005) Urban Informality: Toward an Epistemology of Planning. Journal of the American Planning Association. 71 (7): 147-158.

Scott J (1989) Everyday forms of resistance. The Copenhagen Journal of Asian Studies 4: 33-62.

Simone A (2004) The informal. In: For the city yet to come: changing African Life in Four Cities, Durham: Duke University Press, pp. 21-62.

Soto H De (1995) ¿Por qué importa la economía informal? In: El sector informal en América Latina: Dos décadas de análisis, Mexico DF: Consejo Nacional para la Cultura y las Artes, pp. 275-286.

Swyngedouw E, Moulaert F and Rodriguez A (2005) 'The World in a Grain of Sand': Large-Scale Urban Development Projects and the Dynamics of 'Glocal' Transformations. In: Moulaert F, Rodriguez A, and Swyngedouw E (eds), The Globalized city: Economic Restructuring and Social Polarisation in European Cities, Oxford: Oxford University Press.

Varley A (2013) Postcolonialising informality? Environment and Planning D: Society and Space 31(1): 4-22. 